\title{
Негативное влияние курения на окружающую среду и здоровье молодежи профессиональных образовательных организаций города Нерюнгри РС (Я)
}

\author{
Скитилягина А.И., студентка, \\ ГБПОУ РС (Я) «Нерюнгринский медицинский колледж», \\ 2. Нерюнгри \\ E-mail: nermedu@mail.ru
}

\section{Научный руководитель: преподаватель Кириллина Р.С.}

Курение не только вредит вашему здоровью, но и имеет огромное влияние на окружающую среду. Каждый раз, когда вы курите сигарету, химические вещества выбрасываются в атмосферу, загрязняя воздух. Приблизительно 5 миллионов гектаров леса каждый год уничтожается для сушки табака. Окурки являются наиболее распространенными токсичными отходами на наших дорогах, и, вопреки распространенному мнению, они не разлагаются полностью. Токсические химические вещества в окурках представляют собой угрозу для наших водных экосистем и для пресноводных микроорганизмов [1].

В организме человека нет ни одного органа или системы, на которые бы не оказывал вредного влияния табачный дым и его составные части. Смесь из более чем 4 тысяч химических веществ, содержащихся в табачном дыме, достигает всех тканей и наносит вред всем жизненным процессам. Согласно данным Всемирной организации здравоохранения, около 90-95\% рака легких, 40-45\% всех видов рака и 20-25\% сердечнососудистых заболеваний обусловлено курением. Риск умереть от рака легкого у курящих мужчин в 22 раза выше, чем у некурящих. Курение является основной причиной возникновения злокачественных новообразований губы, полости рта и глотки, гортани, пищевода [2].

Учитывая данные о распространенности курения, полученные при выборочных эпидемиологических обследованиях, в РФ проживает около 20 млн. курящих мужчин и 5 млн. курящих женщин. Среди курящих около 80\% хотели бы отказаться от курения, но из них 47\% курящих мужчин и 57\% курящих женщин нуждаются в помощи специалиста при отказе от курения. Таким образом, около 10 млн. курящих мужчин и женщин нуждаются в помощи специалистов при отказе от курения.

Высокая распространенность курения среди детей и подростков требует разработки и внедрения профилактических программ, направленных на борьбу с курением. Однако их мало и далеко не во всех достигнут реальный, длительный эффект. Изучение личностных и поведенческих особенностей и их влияния на статус курения является одним из наиболее перспективных, но недостаточно разработанных направлений в системе мер по снижению частоты курения среди подрастающего поколения. В настоящее время существует потребность в поиске и изучении различных условий, препятствующих употреблению табака среди детей и подростков, а также в разработке и проведении мероприятий по профилактике курения, направленных на повышение устойчивости личности подростка к началу курения.

Нами было проведено социологическое исследование методом анкетирования среди студенческой молодежи с целью диагностики степени никотиновой зависимости и определения готовности к отказу от курения. Для проведения исследования были 
использованы 2 анкеты: «Степень никотиновой зависимости» - 6 вопросов, «Степень готовности бросить курить» - 30 вопросов [3]. В выборочном анонимном опросе участвовали 58 студентов, из них 36 студентов выпускных групп филиала Алданского политехнического техникума в г. Нерюнгри (далее - АПТ) и 22 студента Нерюнгринского медицинского колледжа (далее - НМК). Возраст участников от 20 лет и старше, из них юношей 51,72\%, девушек 48,28\%. Привлечь к опросу студентов ГАПОУ РС (Я) «Южно-Якутский технологический колледж» не удалось ввиду их занятости в период проведения исследования. Результаты исследования представлены ниже (рис. 1-3).

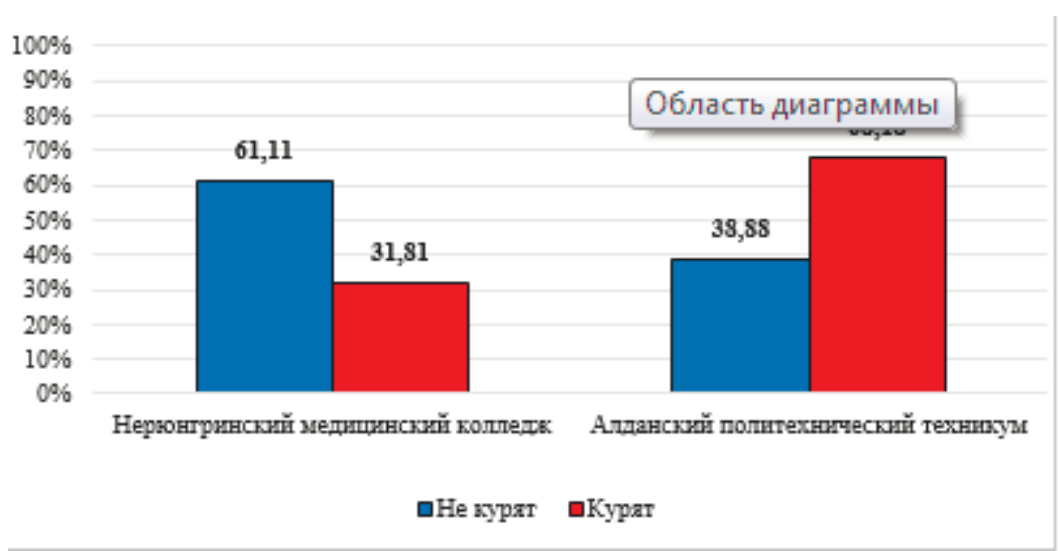

Рис. 1. Соотношение числа курящих и некурящих

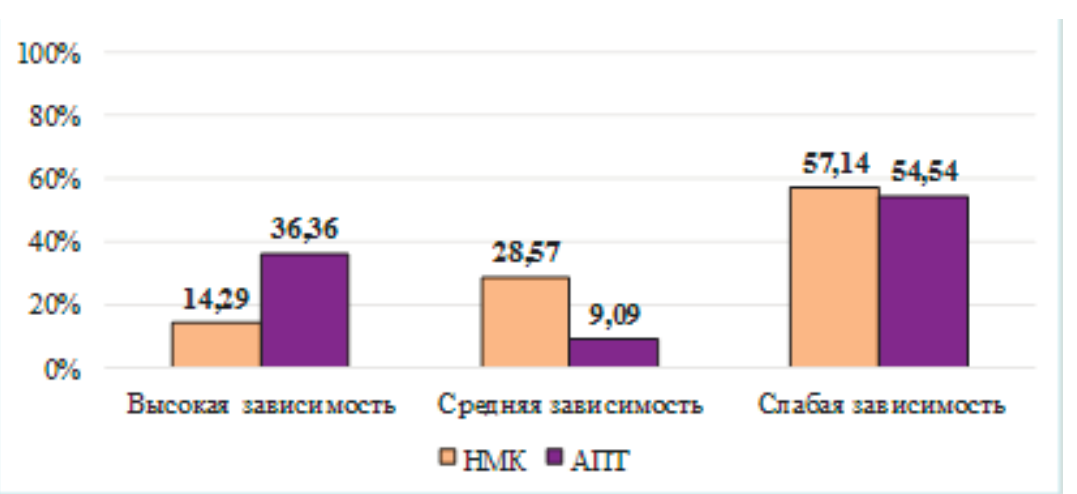

Рис. 2. Степень никотиновой зависимости опрошенного контингента

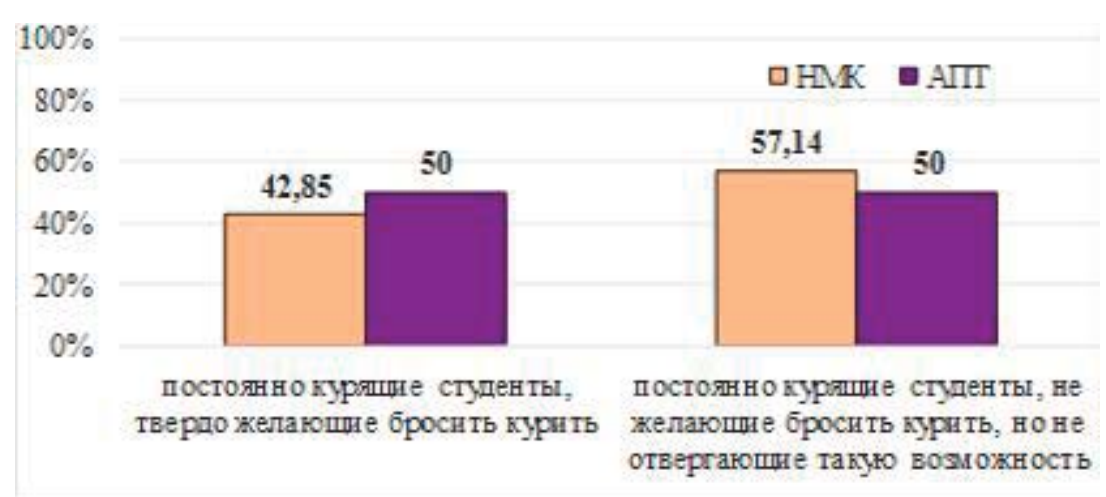

Рис. 3. Степень готовности бросить курить среди опрошенного контингента

Установление факта курения представляет собой несложную задачу, требуется лишь простой опрос респондентов. Анонимность опроса позволяет получить относительно реалистичные данные. 
Результаты опроса показали:

- Среди курящей молодежи преобладают студенты АПТ - 61,11\%; по количеству выкуриваемых сигарет (от 1 пачки и более в день) также преобладают студенты АПТ - 31,82\%, а среди студентов НМК - 4,54\%, высокая степень никотиновой зависимости отмечается у студентов АПТ - 36,36\%, что свидетельствует о большей информированности студентов-медиков о вреде курения.

- Среди курящих студентов медицинского колледжа преобладают первокурсники - 51,72 \%, что свидетельствует о меньшей информированности о вреде курения в сравнении со студентами выпускных групп.

- Твердо желающие бросить курить преобладают среди студентов НМК, что составляет 63,64\%, среди студентов АПТ - 50\%.

- Готовность к отказу от курения напрямую зависит от понимания, к чему приводит табакокурение.

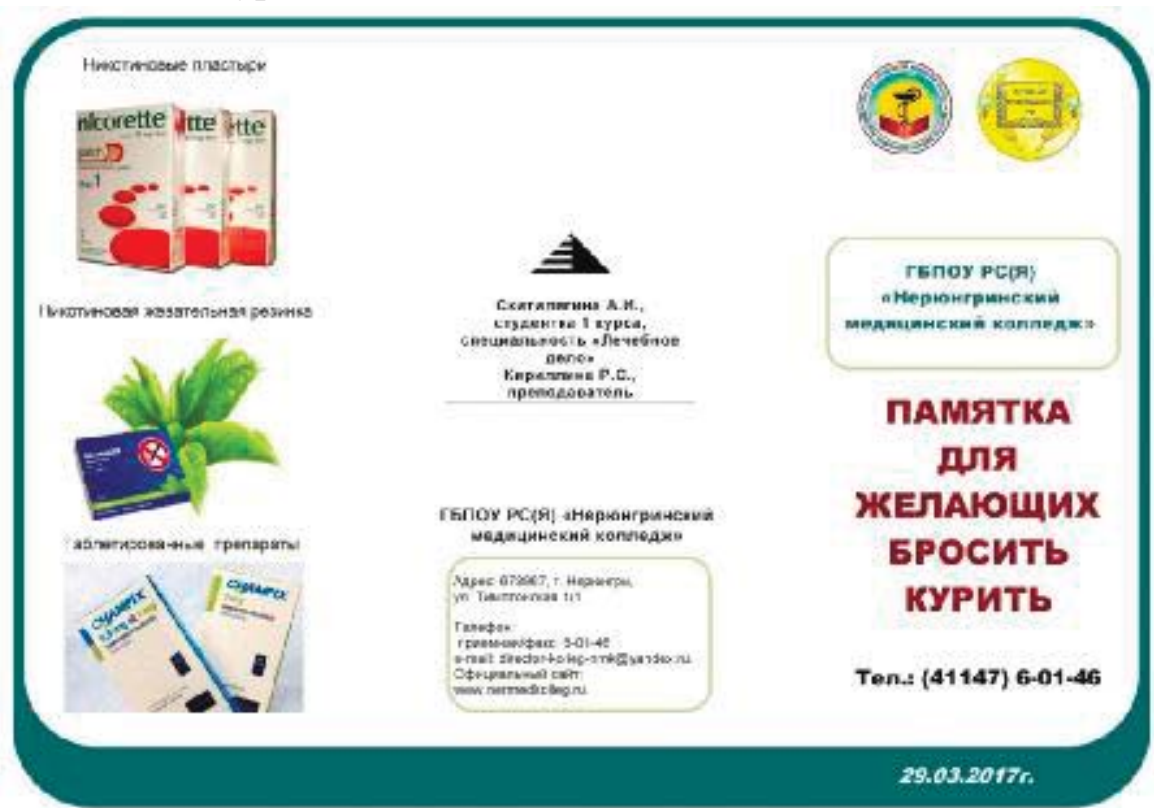

C Lero ienarh opocarh mypurt. Toepao seiurte chanatb Tro nogin ceinac. Het бсль山е rukase orrosopok. Нн saвтра, th понедепиника на с навсто roge.

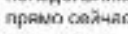

CоOбщите CEONM DEAHGIN $n$

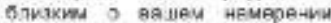

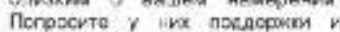

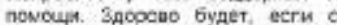

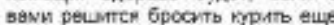

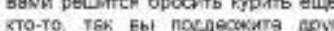
apgra

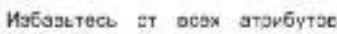

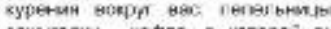

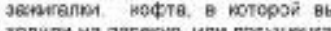

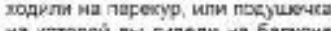

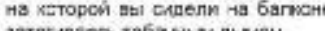
Jarstressoce Ta6s H HLM DLFNOW.

Bsem atru pouj,an borkile we macto

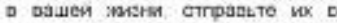
мycounte ob 8 vecsu таятre netar +e

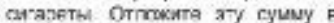

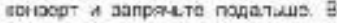
cohue nesecro мacrals 6 es nperine

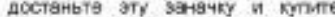

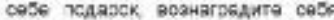
a прсйденитый путь А так noctyräte кандьк местц кизан Gea samocanecti

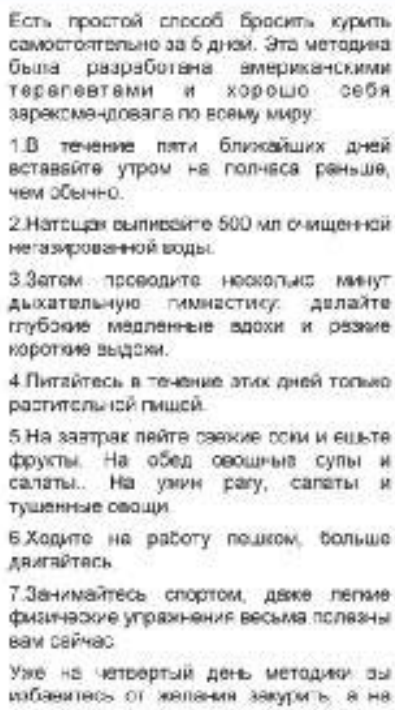

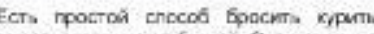

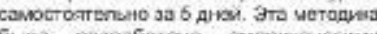

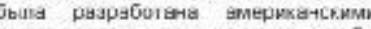
reçneвтвми in xopowo ce6h

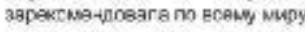

1. встявєйте утрои +8 попнеся реньs YEM $D$ CEAt+O.

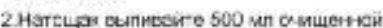

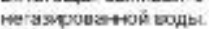

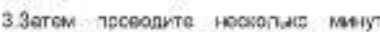
дьхатель-ную пимавстису. Ашлайте

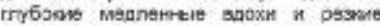

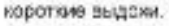

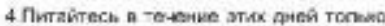
pasтитеก เลй пмшсй

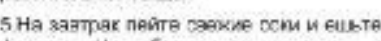

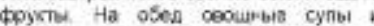
салаты. Ha умин fary, сапеты н

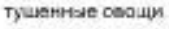

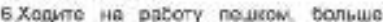
AดURAดTACh

7. Jarnnainecb cnopton, asse nerme

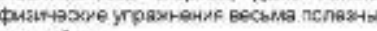
вav car̆uac

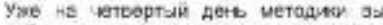

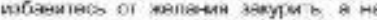

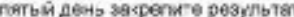

Рис. 4. Памятка для желающих бросить курить

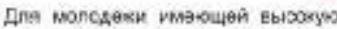

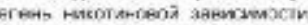

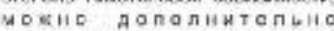

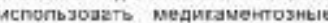

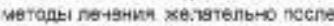

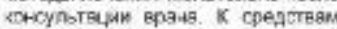
menusaventosmoro netenus or хуеснан от-есятея

- mvrametcabe nract bqu.

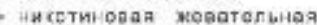
везинека

- aHrorgtodel e codepsemnem HWWOTH-8;

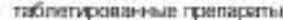

Таценты, sогосые шоาсльзуку

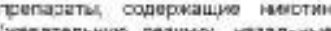

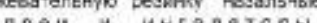
poul hira hatopl. 1 opocano nyputh tauce

ТМоиначия трансдермальны TEPATARTM 4 ACKUX CLCTAL

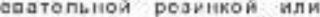
сазальными спреами более

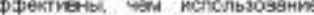

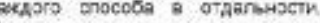
Trerspata o Mafnerfam coogonдениem бoreo quextrutar 
Половина опрошенных студентов осознают вредное влияние курения, готовы отказаться от этой вредной привычки. Необходимо усилить пропаганду ЗОЖ с использованием различных методов санитарного просвещения, таких как: лекция; вечер вопросов и ответов; средства наглядной агитации (плакаты, фотографии, видеофильмы), а также активно использовать печатную продукцию (памятка, брошюра, буклет).

Нами была разработана памятка для студентов с различной степенью никотиновой зависимости, желающих бросить курить (рис. 4).

Табачный дым ядовит сам по себе, к тому же он вступает в реакцию с находящимися в атмосфере загрязняющими веществами. По этой причине вред сигаретного дыма для людей, растений и животных еще больше усиливается.

Задачи медицинских работников в этой сфере согласно рекомендациям ВО3:

1. Способствовать тому, чтобы снизилось число вновь закуривающих, особенно среди подростков и женщин.

2. Оказывать консультативную помощь всем курящим, стремиться к отказу от курения среди них.

3. Стремиться к предотвращению возврата к курению, особенно в течение первого года после отказа, когда высока вероятность рецидива (повторное консультирование) [7].

Меры по борьбе с курением в рамках деятельности службы здравоохранения должны тесно согласовываться и поддерживаться государственной политикой, направленной на контроль за курением, профилактику закуривания, ограничение рекламы табака и прочих мер [7].

Планируется проведение аналогичного социологического исследования на базе высших и средних профессиональных образовательных организаций, и организаций общего образования Нерюнгринского района, а также распространение среди учащейся молодежи памятки для желающих бросить курить.

\section{Список литературы:}

1. 7 фактов, как сигареты влияют на окружающую среду [Электронный ресурс]. - Режим доступа: http://rodovid.me/Tatulie/7-faktov-kak-sigarety-vliyayut-naokruzhayuschuyu-sredu.html.

2. Курение [Электронный ресурс]. - Режим доступа: http://www.grandars.ru/ college/medicina/vliyanie-kureniya.html.

3. Руководство по медицинской профилактике / Под ред. Р.Г. Оганова, Р.А. Хальфина. - М.: ГЭОТАР-Медиа, 2007. - 464 с. 